\title{
ALEXITHYMIA AS RISK FACTOR OF THE DEVELOPMENT OF ADDICTIVE BEHAVIOR OF YOUNG PEOPLE IN THE REPUBLIC OF BELARUS
}

\author{
Sergey Igumnov ${ }^{1,2}$, Konstantin Zbarousky ${ }^{2}$, Pavel Lapanau ${ }^{3}$, \\ Ruslan Popok ${ }^{2}$, Ekaterina Grinevich ${ }^{2}$ \\ ${ }^{1}$ Institute of Psychology, Belarusian State Pedagogical University, Minsk, \\ ${ }^{2}$ Belarusian State University, Minsk, Belarus, \\ ${ }^{3}$ Rechitsa District Hospital, Gomel Region, Belarus
}

Key words: alexithymia, addiction, "new psychoactive substances" (NPS), internet addiction.

\begin{abstract}
Summary
A socio-psychological survey and clinical-psychological research were conducted (level of alexithymia; intensity of internet addiction; individual-characterological personality traits; individual style of coping strategies, behavioral patterns and resources of personality) in the cohort of 150 people at the age of 15-24, average age: $18.9 \pm 1.64, \mathrm{M}: \mathrm{F}=87: 63)$. As a result of the randomization of subjects, 3 groups were detected: themain group (people with traces of developing anaddiction from "new psychoactive substances" (NPS)) (MG, 50 people); a comparison group (people with "non-chemical" forms of addiction (internet addiction) (CG, 50 people) and a reference group (50 people, without addictions and deviant behavior). The research of coping behavior methods, in the category "Search for social support" groups MG and RG significantly differ statistically (probability of passing similarity $\mathrm{p}=0.016, \mathrm{t}=2.45, \mathrm{df}=147$ ) has shown the significance of asocial network support as in the case of NPS addiction. The total score of the Toronto Alexithymia Scale-26-R showed that people from MG (average number 67.66 \pm 8.01 ) and RG (average number 58.92 \pm 8.36 ) statistically differ significantly, with a probability of passing similarity being $p<0.001, t=5.3, d f=147$. Indicators of expressed alexithymia noticeably prevailed in $\mathrm{MG}$ and $\mathrm{CG}$, in comparison with the RG. While researching internet addiction using a subject oriented scale, there was a statistically significant difference between CG
\end{abstract}

and RG. The probability of a passing similarity is $p$ $=0.006, \mathrm{t}=2.82, \mathrm{df}=147$. The received and analyzed study materials are the basis for the development of acombined preventive and rehabilitation program for those with "NPS" addiction and "internet addiction" among teenagers and youth.

\section{Introduction}

The present study involves the factors of analyses of alexithymia development among youth in correlation with addiction characteristics for the development of preventive measures and programs of socio-psychological and medical help for youth in the Republic of Belarus.

Subject of the study - addictive behavior and pathogenetic mechanisms of its development.

Trial subjects - young people (15-24 years old) form the addictive behavior risk group (15-24 yars old) (which is formed due to "NPS" or internet-addiction).

Tasks of the study: 1) to reveal negative social after maths of expressing different forms of addictive behavior (addiction from "NPS", internet-addiction), which developed together with alexithymic features of individuals; 2) to collect empirical data (alexithymia development factors among youth, its gender peculiarities) corresponding with features of different forms of addictive behavior; 3 ) to develop practical addictive behavioral preventive measures as guidelines for modern youth and its after math with the help of sociocultural resources.

In the course of the study, the following research was conducted: socio-demographic, biographic, empiricalpsychological, clinic-psychopathological and predictive factors of addictive behavior development among young people aged 15-24. 
The project design was accomplished (multicenter analytical cross section studies together with observational methods and "case-controls").

The specified I/E criteria (people with serious organic lesion of CNS; active serious somatic diseases; alcohol addiction; those who participate in other clinical researches; those who refused to provide informed consent to conduct research).

The study design was submitted for approval and approved (15.05.2016, record №1/16) by the local Ethics Committee of the Republican Public Association "Belarusian Society of Psychologists".

The methodological procedures for scientific study are the main principles of socio-demographic and clinical-psychological research of diseases conditions with the focus of unified international standards of research be conducted in the area of mental health care.

The aim of this work is to develop a system of socio-cultural preventive measures of addictive behaviors among youth and its aftermaths.

\section{The material and research group cha- racteristics \\ Study design. The subject of the study} - addictive behavior (AB) development processes as maladaptive psychological crisis exit strategy, socio-psychological and clinical predictors and $\mathrm{AB}$ development phenomena, concept model of $\mathrm{AB}$ prevention, development of a specialized medico-psychological help for young people program.

The research methodology is presented by various methods: socio-demographic, biographic, empirical-psychological, clinicpsychopathological and standard package statistics. Statistical processing of the research materials was conducted with the help of statistics packages SPSS -17, Statistical 10.0. Methods of descriptive statistics are used (medians, interquartile range, frequencies), the pattern of variable distributions assessed, analysis of cross tables with calculations of odds ratios (OR), hazard ratios
(HR), credible intervals (CI), comparison of independent samples (MannWhitney U test), factor analysis, and correlation analysis.

The verification of disease state was conducted according to unified standardized methods of clinical, pathopsychological, and paraclinical researches with establishing diagnosis, based on diagnostic criteria for research of ICD-10 [7].

The characteristic of study sample. The randomization of the study sample was conducted (150 people at the age of 15-24) on 3 groups: main (people with an inclination to use a systematically "NPS" in the form of synthetical cannabinoids) (MG), a comparison group (people from risk group focused on the development of "nonchemical" forms of addiction (Internet addiction) (CG), and the reference group (youth representatives, who are characterized by criterion behavior, without addictions and deviant behavior) (RG).

The sample was introduced by people who live in different territories of the Republic of Belarus (Minsk and Gomel regions (oblasts)).

A socio-psychological survey was conducted (in all mentioned groups, based on the consent form principle to take part in the research).

Empirical-psychological research was conducted (in all mentioned

Table 1. The research results of coping ways of behavior, the questionnaire "Ways of Coping” by R. Lazarus was used.

Remarks - data in the graphs is presented with descriptive statistics, where $M$ is mid-score in the group, $S D$ - standard deviation.

\begin{tabular}{|l|c|c|c|c|c|c|}
\hline \multirow{2}{*}{ Coping strategies } & \multicolumn{2}{|c|}{$\begin{array}{c}\text { Main group } \\
\text { (MG) }\end{array}$} & \multicolumn{2}{c|}{$\begin{array}{c}\text { Comparison } \\
\text { group (CG) } \\
\text { (n=50) }\end{array}$} & \multicolumn{2}{c|}{$\begin{array}{c}\text { Reference } \\
\text { group (nG) } \\
\text { (n=50) }\end{array}$} \\
\cline { 2 - 7 } & $\mathrm{M}$ & $\mathrm{SD}$ & $\mathrm{M}$ & $\mathrm{SD}$ & $\mathrm{M}$ & $\mathrm{SD}$ \\
\hline Confrontational coping & 51.9 & 14.8 & 49.2 & 15.0 & 51.2 & 14.1 \\
\hline Distancing & 50.9 & 15.4 & 48.6 & 17.5 & 49.5 & 14.8 \\
\hline Self-control & 58. & 15.7 & 61.6 & 13.4 & 56.1 & 13.0 \\
\hline Search for social support & 23.4 & 17.1 & 61.9 & 15.9 & 56.6 & 15.3 \\
\hline Acceptance of responsibility & 65.3 & 19.2 & 65.7 & 16.2 & 61.7 & 18.2 \\
\hline Avoidance behavior & 47.4 & 14.4 & 45.4 & 16.1 & 44.0 & 14.1 \\
\hline Planning of problem solution & 67.7 & 17.0 & 67.0 & 17.5 & 67.5 & 14.9 \\
\hline Positive revaluation & 56.7 & 14.8 & 57.9 & 16.2 & 55.9 & 14.1 \\
\hline
\end{tabular}

Table 2. The research results of depression level group using the method "Beck's Depression Inventory" by A. Beck (BDI).

" $M$ - mid-score, $S D$ - standard deviation.

\begin{tabular}{|c|c|c|c|c|c|c|}
\hline \multirow[t]{2}{*}{ Factor } & \multicolumn{2}{|c|}{$\begin{array}{l}\text { Main group } \\
(\mathrm{MG})(\mathrm{n}=\mathbf{5 0})\end{array}$} & \multicolumn{2}{|c|}{$\begin{array}{c}\text { Comparison } \\
\text { group } \\
\text { (CG) }(\mathbf{n}=\mathbf{5 0})\end{array}$} & \multicolumn{2}{|c|}{$\begin{array}{c}\text { Reference } \\
\text { group } \\
\text { (RG) }(n=50)\end{array}$} \\
\hline & $\mathrm{n}$ & $\%$ & $\mathrm{n}$ & $\%$ & $\mathrm{n}$ & $\%$ \\
\hline Lack of depression & 41 & 82.0 & 29 & 58.0 & 41 & 82.0 \\
\hline Mild depression & 9 & 18.0 & 14 & 28.0 & 6 & 12.0 \\
\hline Moderate depression & 0 & 0.0 & 4 & 8.0 & 2 & 4.0 \\
\hline Severe depression & 0 & 0.0 & 0 & 0.0 & 1 & 2.0 \\
\hline Extremely severe & 0 & 0.0 & 3 & 6.0 & 0 & 0.0 \\
\hline Score $(\mathrm{M} \pm \mathrm{SD})^{*}$ & 6.2 & 4.0 & 9.5 & 8.2 & 5.8 & 5.0 \\
\hline
\end{tabular}


groups) using psycho-diagnostic methods:

1. Questionnaire "Ways of Coping" by R. Lazarus - to find out individual ways of coping with stress, unproductive behavioral patterns and personality resources [4];

2. Beck's Depression Inventory by A. Beck (BDI) [1];

3. Toronto Alexithymia Scale (TAS-26-R) -to investigate the level of alexithymia $[2 ; 6]$;

4. Questionnaire to define the level of internet - addiction intensity by S.A. Kulakov [5].

Received and analyzed study materials that were used for the basis of developing a complex program of preventive measures to work with "NPS" addictions among teenagers and youth [3].

A registration form was completed by each patient included in the research which had a strict adherence to the attached and specially created instructions which explains how to complete the form.

\section{Received results and their discussion}

The findings of the analysis of empirical-psychological research of people from the main (MG), comparison group (CG) and reference (RG) groups are presented. The analysis was conducted by comparing three samples as well as using table-graphic visual materials.

According to the research results of coping behavior which are shown in the table 1, in the category "Search for social support", MG and RG are significantly different from each other (probability of passing similarity $\mathrm{p}=0.036934$, one-way ANOVA test, Tukey's test, mistake between MS $=279.13 ; \mathrm{df}=147.00$ ), which shows the significance of support by the social group in the case of PAS addiction, and also the preventive and rehabilitation programs implementation. Therefore, the respondents of the MG have a stronger need to be in a group and to get feedback while the participants of the reference group tend to be autonomous and ready to make personal decisions.

As shown in the table 2, depression factors in all groups are almost equal, but there is some specificity of $\mathrm{MG}$ - in the given group there were people found to have moderate, severe and extremely severe depression, which can be explained as a generally poor emotional life of the respondents, as well as specific features of sampling (absence in the MG people with clinically shown depression symptoms). Nevertheless, to specify the statistical significant difference between groups was by using Student's test for unconnected sampling, according to which $t=2.6$

Table 3. The results of alexithymia research using Toronto Alexithymia Scale (TAS-26-R). " $M$ - mid-score, $S D$ - standard deviation.

\begin{tabular}{|l|l|l|l|l|l|l|}
\hline Criterion of estimation & \multicolumn{2}{|l|}{$\begin{array}{l}\text { Main group } \\
\text { (MG) n=50 }\end{array}$} & \multicolumn{2}{l|}{$\begin{array}{l}\text { Comparison } \\
\text { group } \\
\text { (CG) } \mathbf{n}=\mathbf{5 0}\end{array}$} & \multicolumn{2}{l|}{$\begin{array}{l}\text { Refere n ce } \\
\text { group (RG) } \\
\text { n=50 }\end{array}$} \\
\cline { 2 - 7 } & $\mathrm{n}$ & $\%$ & $\mathrm{n}$ & $\%$ & $\mathrm{n}$ & $\%$ \\
\hline No alexithymia & 17 & 34.0 & 30 & 60.0 & 34 & 68.0 \\
\hline Alexithymia is probable & 17 & 34.0 & 14 & 28.0 & 14 & 28.0 \\
\hline Severe alexithymia & 16 & 32.0 & 6 & 12.0 & 2 & 4.0 \\
\hline Score $(\mathrm{M} \pm \mathrm{SD})^{*}$ & 67.66 & 8.01 & $59.24^{1}$ & 11.83 & $58.92^{2}$ & 8.36 \\
\hline
\end{tabular}

at upper significance level of 2.63 , which indicates the presence of tin the ambiguity area, but very close to a significant area, which allows to conclude that there is some tendency of how depression symptoms appear in the RG (risk group with internet-addiction).

According to the received results from the Toronto Alexithymia Scale (TAS-26-R), which are shown in the table 3, total score numbers in MG (mid-score is 67.66) and RG (mid-score is 58.92) are significantly different from each other, but indexes of shown alexithymia notably prevail in MG, which can be expressed in significant difficulties in the recognition of one'sown feelings and emotions, reflection, difficulties inexpressing empathy, also it is difficult to build emotionally stable relationships with people and it can be the reason to take PAS.

\section{Conclusions}

The research of personal and social-demographic characteristics of young people with the risk of development of addictive behavior has shown that:

1. The participants of the main group (people with an inclination to use systematically "NPS") and internet addiction risk group (comparison group) share expressed needs to be in a social group and to get a feedback, while at the same time the participants of the reference group tend to be autonomous and ready to make individual decisions;

2 . The internet addiction risk group shows the development of some tendencies toward depression symptoms;

3. There is noticeable data predominance of expressed alexithymia in the main group; it can be seen as significant difficulties in the area of recognition and anexpression of one'sown feelings and emotions, reflection, problems with empathy, also problems with building emotionally stable relationships with other people;

4. The study materials are the basis for the development of combined preventive and rehabilitation programs for those with "NPS" addiction and "Internet addiction" among teenagers and youth. 


\section{References}

1. Beck AT, Ward CH, Mendelson M, Mock J, Erbaugh J. An inventory for measuring depression. Archives of General Psychiatry 1964; 4:19-36.

2. Eresko DB. Alexithymia and methods of its diagnosis at borderline psychosomatic disorders. SPb: V.M. Bekhterev Psychoneurological Research Institute 2005;25.

3. Igumnov SA, Zuikova NL, Burtsev AA, Lapanov PS. Overarching policy of addiction prevention from "new psychoactive substances" at teenagers. Ambulatory and hospital psychotherapeutic and psychological help today (interdisciplinary interaction): proceedings of the $13^{\text {th }}$ and $14^{\text {th }}$ Russian National Public Professional Medical Psychotherapeutic conference. Moscow, December 22, 2016. RUDN 2016; 105-108.

4. Krukova TL, Kuftyak EV. Coping strategies questionnaire (procedure adaptation WCQ). Practical Psychologist Journal M. 2007; 3: 93-112.

5. Kulakov SA. Practical course of clinical psychology and psychotherapy of teenagers. SPb, Rech, 2004; 464.

6. Taylor GJ, Ryan DP, Bagby RM. Toward the development of a new self-report alexithymia scale. Psychotherapy and Psychosomatics 1985; 44:191-199.

https://doi.org/10.1159/000287912

7. The ICD-10 classification of mental and behavioural disorders: diagnostic criteria for research. Geneva: World Health Organization, 1993. http://www.who.int/iris/handle/10665/37108

\section{ALEKSITIMIJA KAIP RIZIKOS VEIKSNYS BESIVYSTANČIŲ JAUNŲ ŽMONIŲ ELGESIUI BALTARUSIJOS RESPUBLIKOJE S.Igumnov, K.Zbarousky, P.Lapanau, R.Popok, E.Grinevich}

Raktažodžiai: aleksitimija, priklausomybè, naujos psichoaktyvios medžiagos (NPS), priklausomybè nuo interneto.

\section{Santrauka}

Buvo atliktas socialinis ir psichologinis tyrimas bei klinikinèpsichologinè analizè (aleksitimijos lygis, priklausomybès nuo interneto intensyvumas, individualūs asmenybès bruožai, individualus įveikimo strategijų stilius, elgesio modelių ir asmenybès resursai) 150 žmonių kohortoje, kurių amžius 15-24 metai, amžiaus vidurkis: $18,9 \pm 1,64$, vyr.: mot.: $=87: 63)$. Atsitiktinio pasirinkimo principu buvo sudarytos 3 grupès: pagrindinè grupè - žmonès su besivystančios priklausomybès nuo naujų psichoaktyvių medžiagų (NPS) pėdsakais (MG - 50 žmoniu); palyginamoji - žmonès su ne cheminèmis priklausomybės formomis, turintys priklausomybę nuo interneto $(\mathrm{CG}-50$ žmonių) ir atskaitinè grupè ( $\mathrm{RG}-50$ žmonių) be priklausomybės ir elgesio nukrypimų. Elgesio įveikimo metodų tyrime, kategorijoje „Socialinès paramos paieška“, grupès MG ir RG statistiškai ženkliai skyrèsi ir parodè artimo tinklo paramos svarbą, kaip ir NPS priklausomybių atveju. Toronto aleksitimijos (alexia+thymus) (skalès lygis-26-R) rezultatas parodè, kad žmonès iš MG (vidutinis skaičius 67,66 $\pm 8,01$ ) ir RG (vidutinis skaičius 58,92 $\pm 8,36)$ grupių statistiškai reikšmingai skyrėsi $(<0,001$, $\mathrm{t}=5,3, \mathrm{df}=147)$. Aleksitimijos išraiškos rodikliai pastebimai dominavo MG ir CG grupèse, lyginant su $R G$ grupe $(p=0,006, t=$ $2,82, \mathrm{df}=147)$. Gauta ir išanalizuota tyrimų medžiaga yra pagrindas kompleksinei prevencinei ir reabilitacinei programai, skirtai paaugliams ir jaunimui nuo NPS priklausomybės ir priklausomybès nuo interneto plètoti.

Adresas susirašinèti: sigumnov67@gmail.com

Gauta 2018-10-10 